\title{
PENDUGAAN LAJU SEDIMENTASI DI PERAIRAN TELUK BENOA - BALI BERDASARKAN CITRA SATELIT
}

\author{
SEDIMENTATION RATE IN BENOA BAY COASTAL WATERS - BALI \\ BASED ON SATELLITE IMAGERY
}

\author{
Try Al Tanto', Aprizon Putra', Gunardi Kusumah', A. Riza Farhan², Widodo S. Pranowo ${ }^{2,3}$, \\ Semeidi Husrin² dan Ilham ${ }^{1)}$ \\ ${ }^{1}$ Loka Riset Sumber Daya dan Kerentanan Pesisir, Kementerian Kelautan dan Perikanan \\ Jalan Raya Padang - Painan Km.16 Bungus - Kota Padang \\ ${ }^{2}$ Pusat Riset Kelautan, Kementerian Kelautan dan Perikanan, Jakarta \\ ${ }^{3}$ Prodi Teknik Hidrografi, Sekolah Tinggi Teknologi Angkatan Laut, Jakarta \\ e-mail : try.altanto@gmail.com
}

Diterima tanggal: 14 Juni 2017 ; diterima setelah perbaikan: 02 Desember 2017 ; Disetujui tanggal: 04 Desember 2017

\begin{abstract}
ABSTRAK
Perairan Teluk Benoa Bali memiliki 6 sungai (tukad) yang bermuara pada perairannya. Tukad Mati dan Tukad Badung adalah 2 sungai terbesar pemberi pasokan sedimen. Pembangunan reklamasi di pelabuhan Benoa dan pembangunan Jalan Tol melintasi Teluk Benoa diduga meningkatkan sedimentasi. Tujuan penelitian ini adalah untuk mengetahui kejadian sedimentasi di perairan Teluk Benoa, dan memperoleh kisaran sedimentasi secara spasial yang terjadi dalam rentang 9 tahun terakhir. Analisis pendugaan sedimentasi dilakukan secara spasial berupa sebaran pengendapan sedimentasi di dasar perairan dengan menggunakan citra satelit Spot - 6 dan Landsat 7. Hasil yang diperoleh adalah luasan sedimentasi pada tahun 1997 sebesar 1640,78 ha mengalami penurunan luasan menjadi 1480,57 ha (tahun 2006) dengan laju perubahan sebesar positif $-160,21$ ha (-20,03 ha/tahun). Namun, luasan sedimentasi kembali bertambah menjadi 1531,93 ha pada tahun 2012 (laju perubahan negatif $+8,56$ ha/tahun), bahkan menjadi 1966,14 ha pada tahun 2015 (laju perubahan negatif $+144,74$ ha/tahun).
\end{abstract}

Kata kunci: Sedimentasi, Teluk Benoa, Bali, citra satelit, analisis spasial, spot-6, landsat-7

\begin{abstract}
Benoa Bay coastal waters have six rivers estuarine. Tukad Mati and Tukad Badung are two big rivers may sediment sources to the bay. Reclamation in the port area and highway passing through over the bay are predicted increasing the sedimentation. This objective research is determining the incidence of sedimentation in the bay, and obtaining spatially range of sedimentation during 9 years. Analysis have been done by investigating the spatial sediment deposition using satellite imagery of Spot - 6 and Landsat 7. The results showing that are sedimentation area in 1997 (1640,78 ha) has been decreased to becoming 1480,57 ha (in 2006). Means that a positive rate change of -160,21 ha (-20,03 ha/year). Thereafter, the sedimentation back increasingly, it becomes 1531,93 ha in 2012 (a negative rate change to +8,56 ha/year). It even becomes 1966,14 ha in 2015 (a negative rate change to $+144,74$ ha/year).
\end{abstract}

Keywords: sedimentation, Benoa Bay, Bali, satellite imagery, spatial analysis, spot-6, landsat-7

Pendugaan Laju Sedimentasi di Perairan Teluk Benoa - Bali Berdasarkan Citra Satelit - Try Al Tanto, Aprizon Putra, Gunardi Kusumah, A. Riza Farhan, Widodo S. Pranowo, 


\section{PENDAHULUAN}

Undang-Undang RI No. 1 Tahun 2014 tentang perubahan atas UU No. 27 Tahun 2007, disebutkan bahwa wilayah pesisir merupakan daerah peralihan antara ekosistem darat dan laut yang dipengaruhi oleh perubahan di darat dan laut. Wilayah pesisir sangat dinamis, dimana dinamika pesisir dapat terjadi secara alami karena pengaruh angin, gelombang, dan arus maupun yang disebabkan campur tangan manusia (Tanto dkk., 2017; Jamalludin dkk., 2016; Muldiyatno dkk., 2016; Risandi dkk., 2015). Pembangunan saat ini banyak diarahkan di daerah pesisir mengingat lahan di daerah kota semakin terbatas, sehingga daerah pesisir menjadi alternatif dialihkannya kegiatan - kegiatan seperti industri, perdagangan, pariwisata, dan sebagainya (Pearson et al., 2016). Hal tersebut menjadikan wilayah pesisir sangat rentan terjadi bencana (Dahuri, 2003).

Kawasan Teluk Benoa berada pada bagian tenggara Pulau Bali, yang merupakan perairan lintas Kabupaten Badung dan Kota Denpasar. Kawasan Teluk Benoa dikelilingi oleh 12 desa/kelurahan (BPS Provinsi Bali, 2012 dalam Sudiarta dkk., 2013). Pada kawasan ini telah terjadi reklamasi pada Pulau Serangan dan pembangunan jalan Tol, perubahan beberapa bagian area Pelabuhan Benoa, serta cukup berkembangnya pembangunan di area pesisir kawasan tersebut. Hal ini dapat memberikan dampak cukup besar pada kawasan perairannya. Sarbidi (2005) mengatakan bahwa pembangunan yang terus menerus dilakukan di wilayah pesisir menimbulkan banyak permasalahan. Pembangunan gedung - gedung tinggi memberikan beban yang berat terhadap tanah. Pengambilan air tanah secara berlebihan menyebabkan tanah semakin rapuh dan akhirnya menyebabkan amblesan tanah atau land subsidence (Gemilang dkk., 2017a). Umumnya perubahan tutupan lahan yang banyak terjadi di wilayah pesisir yang semula merupakan sabuk hijau (greenbelt) berupa pepohonan dan hutan bakau (mangrove) menjadi lahan untuk pertambakkan, pelabuhan, permukiman, dan kawasan industri yang telah menggangu kestabilan ekosistem di daerah pesisir (Dhiaududdin dkk., 2017). Hal tersebut diduga dapat menyebabkan terjadinya degradasi lingkungan dan permasalahan, salah satunya berupa akresi/sedimentasi di dasar perairannya (Wisha dkk., 2015).

Sedimentasi didefinisikan sebagai pengangkutan, melayang (suspensi) atau mengendapnya material fragmental oleh air (Gemilang dkk., 2017b). Menurut Rijn (1993) dalam Rachman dkk. (2016), sedimentasi adalah masuknya muatan sedimen ke dalam suatu lingkungan perairan tertentu melalui media air dan diendapkan pada lingkungan perairan tersebut. Sedimentasi merupakan akibat dari adanya erosi dan memberikan dampak yang banyak, pada muara sungai pengendapan sedimen akan mengurangi volume efektifnya. Sebagian besar jumlah sedimen dialirkan oleh sungai - sungai yang mengalir ke muara, hanya sebagian kecil yang berasal dari longsoran tebing sungai atau longsoran tebing oleh limpasan permukaan. Pada aliran sungai, partikel dan unsur hara yang larut dalam aliran permukaan akan mengalir ke sungai besar dan muara, sehingga terjadi pendangkalan. Keadaan tersebut mengakibatkan daya tampung sungai dan muara menjadi turun sehingga timbul banjir dan penyuburan air secara berlebihan atau eutrofikasi. Proses sedimentasi menurut Leeder (1983) menghasilkan: 1) Bahan terlarut, semua bahan organik dan an-organik yang terangkut sebagai larutan oleh air yang mengalir; 2) Bahan padat atau bed load, semua bahan kasar dari mineral dan batu yang terangkut di sepanjang dasar sungai; dan 3) Total bahan yang terangkut sungai atau total stream load adalah semua bahan organik dan an-organik yang terangkut lewat sebuah stasiun pengukur dalam bentuk suspensi atau bed load.

Tujuan dilakukan penelitian ini adalah untuk mengetahui kejadian sedimentasi di perairan Teluk Benoa Bali serta memperoleh kisaran laju sedimentasi secara spasial yang terjadi dalam rentang beberapa tahun terakhir.

\section{BAHAN DAN METODE}

Penelitian ini dilakukan pada area lokasi kawasan Teluk Benoa Bali (Gambar 2). Dilakukan prasurvei pada bulan April 2016 untuk melihat kondisi awal di lapangan, diantaranya sekitar Pulau Serangan, Tahura, dan kondisi Teluk Benoa secara umum (Gambar 1).

Jenis penelitian ini tergolong kepada penelitian kuantitatif dengan pendekatan deskriptif (Wisha dkk., 2014; Pabundu, 2005). Penelitian deskriptif adalah penelitian yang mendeskripsikan suatu gejala, fakta, peristiwa atau kejadian yang sedang atau sudah terjadi. Penelitian kuantitatif merupakan suatu proses menemukan pengetahuan yang menggunakan data berupa angka sebagai alat menganalisis keterangan mengenai apa yang ingin diketahui (Pabundu, 2005).

Analisis laju sedimentasi di perairan Teluk Benoa Bali dilakukan dengan pendekatan secara spasial 


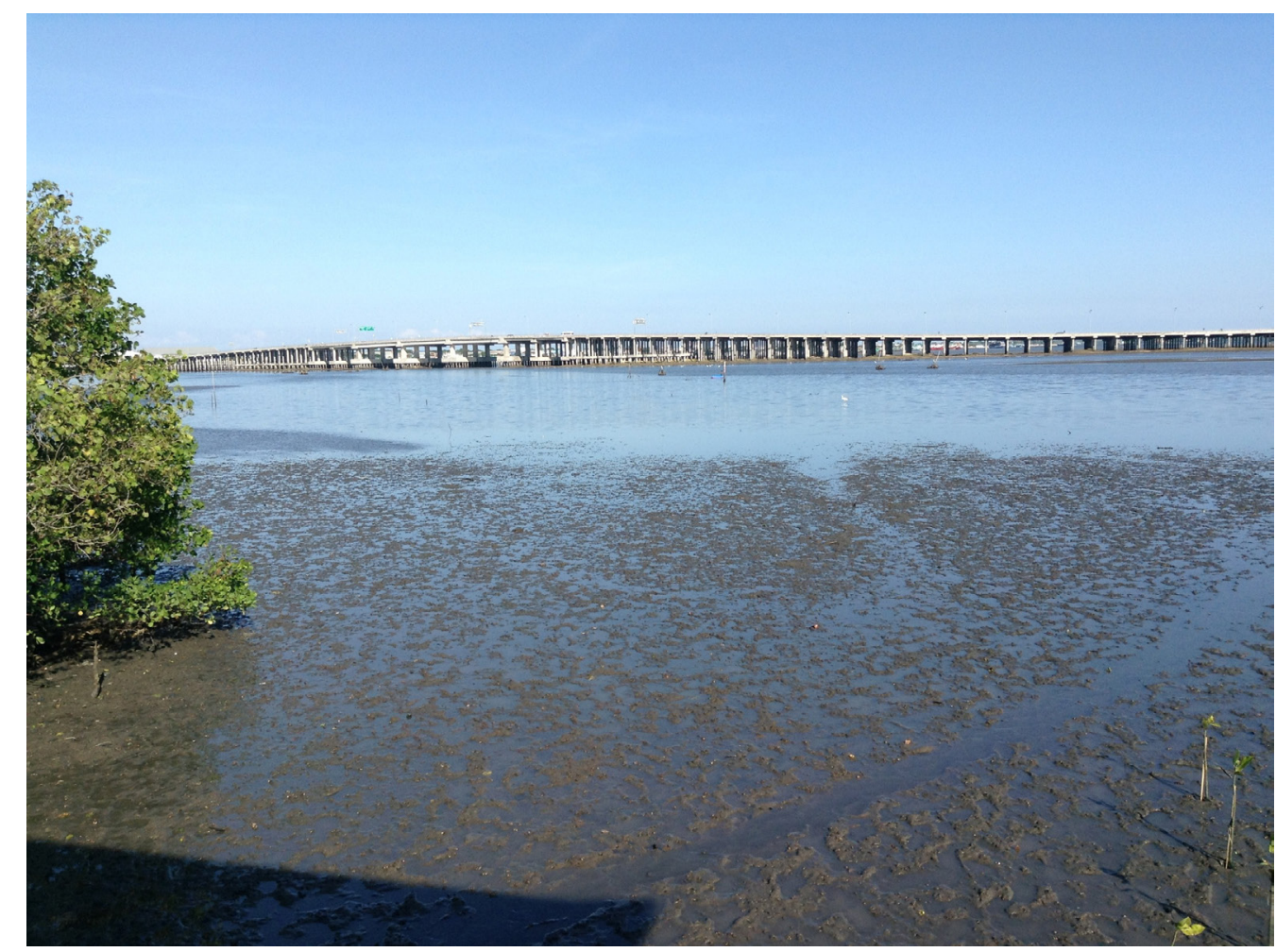

Gambar 1. Pendangkalan di perairan Teluk Benoa (terlihat saat kondisi air surut), Dokumentasi: LPSDKP (2016)

Figure 1. Silted Up in The Waters of Benoa Bay (seen during low tide conditions), Documentation: LPSDKP (2016)

tanpa memperhatikan perbedaan karakteristik teknis dari SPOT-6 dan Landsat-7 (Parwati and Purwanto, 2017; Carolita et al., 2015). Asumsi laju sedimentasi didasarkan kepada berupa sebaran pengendapan sedimentasi di dasar perairannya (Gemilang dkk., 2017c), yaitu:.

Kompilasi data sekunder time series dari citra Spot - 6 tahun 2006, 2012 dan 2015 dengan resolusi 1,5 x 1,5 $\mathrm{m}$ yang diperoleh dari Infrastructure Development of Space Oceanography (INDESO), yaitu suatu proyek pemetaan untuk memperkuat revolusi biru dari Badan Penelitian dan Pengembangan Kelautan dan Perikanan (BALITBANG KP), serta menggunakan citra satelit Landsat 7+ETM perekaman tahun lebih lama (tahun 1997).

Hasil survei lapang dan tabulasi data sekunder digunakan untuk menganalisis kondisi lingkungan kawasan perairan Teluk Benoa berdasarkan training area seluas 7528,55 ha (Gambar 2) dan selanjutnya dianalisis menggunakan SIG untuk menghasilkan informasi sebaran sedimentasi secara time series di kawasan perairan Teluk Benoa.

Laju perubahan sedimentasi secara time series diperoleh dari analisis spasial pengendapan sedimentasi sehingga dapat diketahui luas perubahan yang terjadi pada kawasan tersebut. Analisis laju perubahan secara time series, dijelaskan dalam formula berikut (ENVI Classic help, 2008).

$$
\mathrm{V}=(\mathrm{N} 2-\mathrm{N} 1) / \mathrm{N} 1 \times 100 \%
$$

Keterangan:

$$
\begin{array}{ll}
\mathrm{V} & =\text { laju perubahan (\%) } \\
\mathrm{N} 1 & =\text { luas tahun pertama (ha) } \\
\mathrm{N} 2 & =\text { luas tahun } \mathrm{ke}-\mathrm{n}(\mathrm{ha})
\end{array}
$$

\section{HASIL DAN PEMBAHASAN}

Hasil klasifikasi secara spasial dari analisis SIG peta sebaran pengendapan sedimen secara time series di perairan Teluk Benoa Bali adalah sebagai berikut (Tabel 1 dan 2; Gambar 3 dan 4). Kelas untuk pasir yang merupakan kejadian sedimentasi dan pasir yang mengendap di perairan dangkal hasil klasifikasi ditampilkan dengan warna kuning.

Pada tahun 1997, sedimentasi (warna kuning) yang terjadi pada perairan Teluk Benoa Bali adalah seluas 1640,78 ha. Kejadian sedimentasi terlihat pengurangan hingga paa tahun 2006 seluas 1480,57 ha. Hal ini dapat saja terjadi diduga karena adanya bendungan 


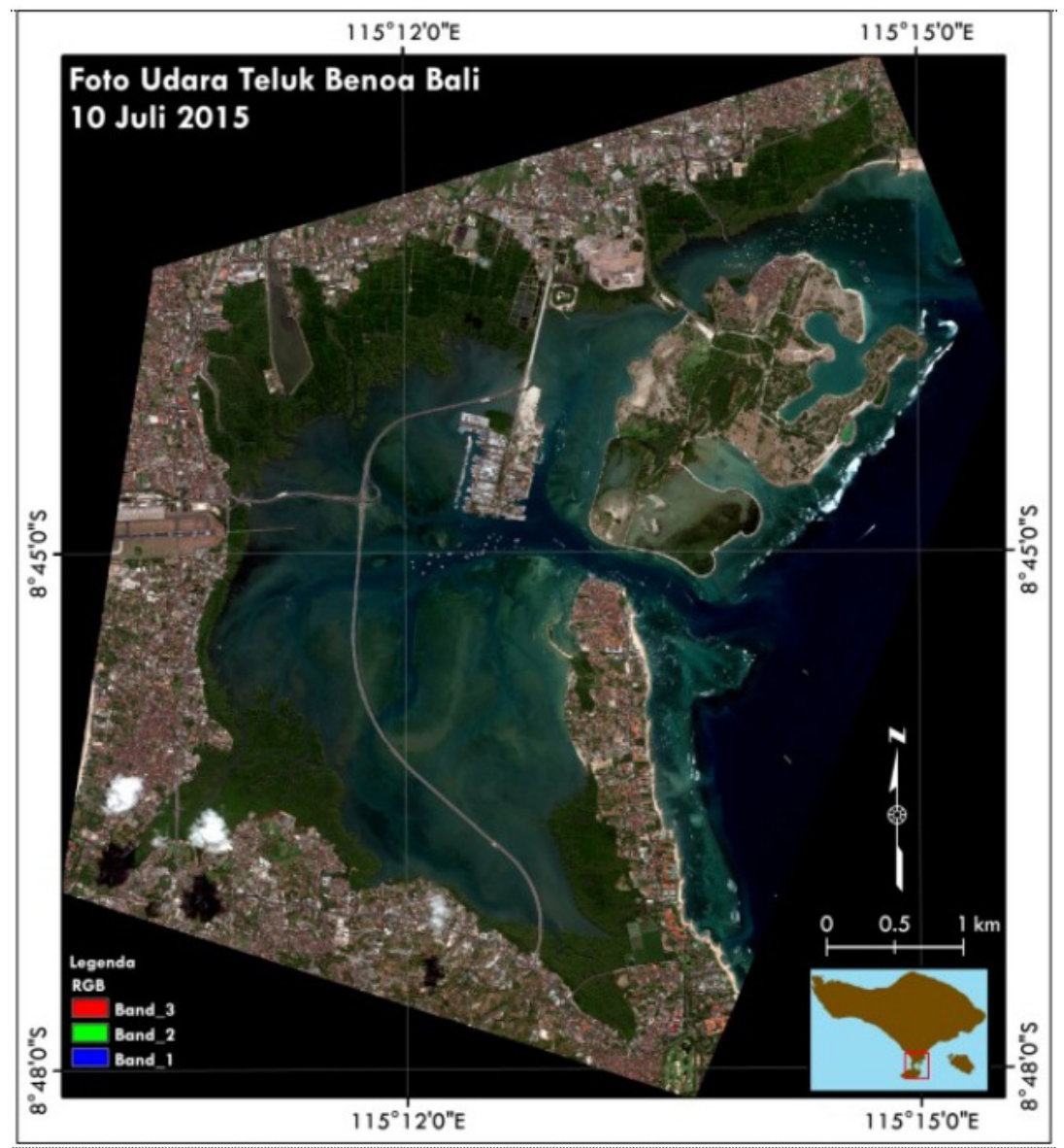

Gambar 2. Citra Satelit Spot - 6 Kawasan Perairan Teluk Benoa Berdasarkan Training Area.

Figure 2. Spot Satellite Image - 6 Benoa Bay Waters Area Based on Training Area.

paa salah satu aliran sungai yang bermuara ke Teluk Benoa, yaitu di Tukad Badung. Berdasarkan informasi dari diskusi yang dilakukan dengan pihak Balai Wilayah Sungai Bali - Penida, Kementerian PUPR di Denpasar, pembangunan bendungan Tukad Badung dilakukan sekitar tahun 1996. Bendungan tersebut digunakan sebagai penghalang sedimen yang berasal dari Sungai/Tukad Badung yang merupakan masukan terbesar sedimentasi di Teluk Benoa. Hal tersebut berkorelasi dengan menurunnya sedimentasi di perairan Teluk Benoa pada rentang beberapa tahun setelah pembangunan tersebut. Artinya sedimentasi yang masuk ke dalam teluk berkurang, sedangkan sedimentasi yang sudah berada di dasar perairannya dapat tergerus oleh arus dan gelombang sehingga menuju luar teluk. Laju pengurangan sedimentasi yang terjadi pada rentang tahun 1997 sampai 2006 adalah $-9,76 \%$ atau sekitar 160,21 ha yang berarti laju sedimentasi berkurang sebesar 20,03 ha/tahun atau $1,22 \%$ per tahunnya (Gambar 3).

Sedangkan dalam rentang tahun 2006 sampai 2012, kembali terjadi penambahan luasan area sedimentasi di perairan Teluk Benoa sebesar negatif $+51,36$ ha atau negatif $+3,47 \%$, artinya luasan sedimentasi bertambah pada dasar perairan Teluk Benoa sebesar 8,56 ha/tahun $(0,58 \%$ per tahun). Hal yang sama juga terjadi dalam rentang tahun 2012 - 2015, terjadi penambahan luasan area sedimentasi di perairannya (Gambar 4) sebesar negatif $+434,21$ ha atau negatif $28,34 \%$ yang berarti perubahan luasan sedimentasi pada dasar perairan tersebut sebesar negatif 144,74 ha/tahun $(9,45 \%$ per tahun). Kemungkinan dari kejadian peningkatan luasan area sedimentasi di dasar perairan tersebut dapat terjadi karena adanya kegiatan pengerukan oleh pihak Pelabuhan Benoa (Pelindo 3), demi menjaga alur pelayaran kapal masuk dan keluar teluk. Namun, dalam rentang sekitar tahun 1995 - 1998 juga telah terjadi perubahan secara signifikan daratan di Pulau Serangan, yang awalnya sekitar 111 ha menjadi 481 ha (Darmawan, 2013). Hal tersebut tentunya juga berdampak pada beberapa pantai di sekitarnya teluk, bahkan terhadap teluk sendiri (kejadian abrasi dan sedimentasi). Untuk kejadian sedimentasi, dapat terjadi di dalam teluk sendiri yang diduga berasal dari bahan urugannya. 
Tabel 1. Luasan sebaran sedimentasi

Table 1. Extent of Sedimentation Distribution

\begin{tabular}{lllll}
\hline \multicolumn{5}{c}{ Tahun } \\
\hline Tutupan perairan & 1997 & 2006 & 2012 & 2015 \\
Sedimentasi (ha) & $1.640,78$ & $1.480,57$ & $1.531,93$ & $1.966,14$ \\
\hline
\end{tabular}

Tabel 2. Laju perubahan sebaran sedimentasi

Table 2. The Rate of Change of Sedimentation Distribution

\begin{tabular}{|c|c|c|c|c|}
\hline Tutupan Peraira & 1997 & Tahun & Perubahan (ha) & Laju \\
\hline Sedimentasi & $1.640,78$ & $1.480,57$ & $-160,21$ & $-9,76 \%$ \\
\hline Tutupan Perairan & 2006 & 2012 & Perubahan & Laju \\
\hline Sedimentasi & $1.480,57$ & $1.531,93$ & $+51,36$ & $+3,47 \%$ \\
\hline Tutupan Perairan & 2012 & 2015 & Perubahan & Laju \\
\hline Sedimentasi & $1.531,93$ & $1.966,14$ & $+434,21$ & $+28,34 \%$ \\
\hline
\end{tabular}

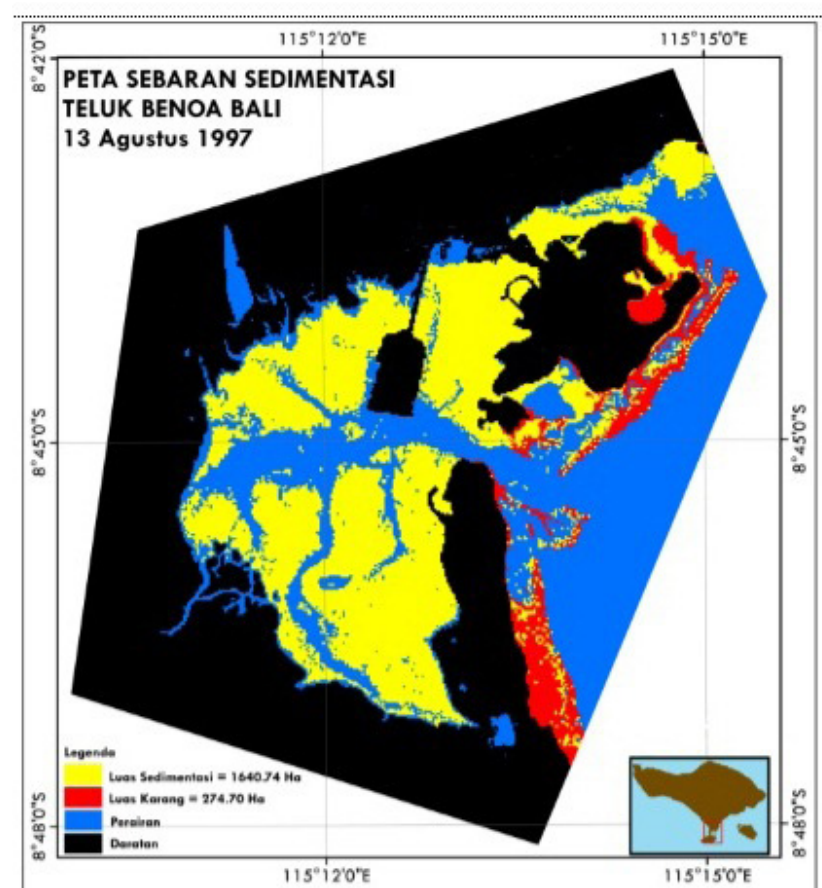

(a)

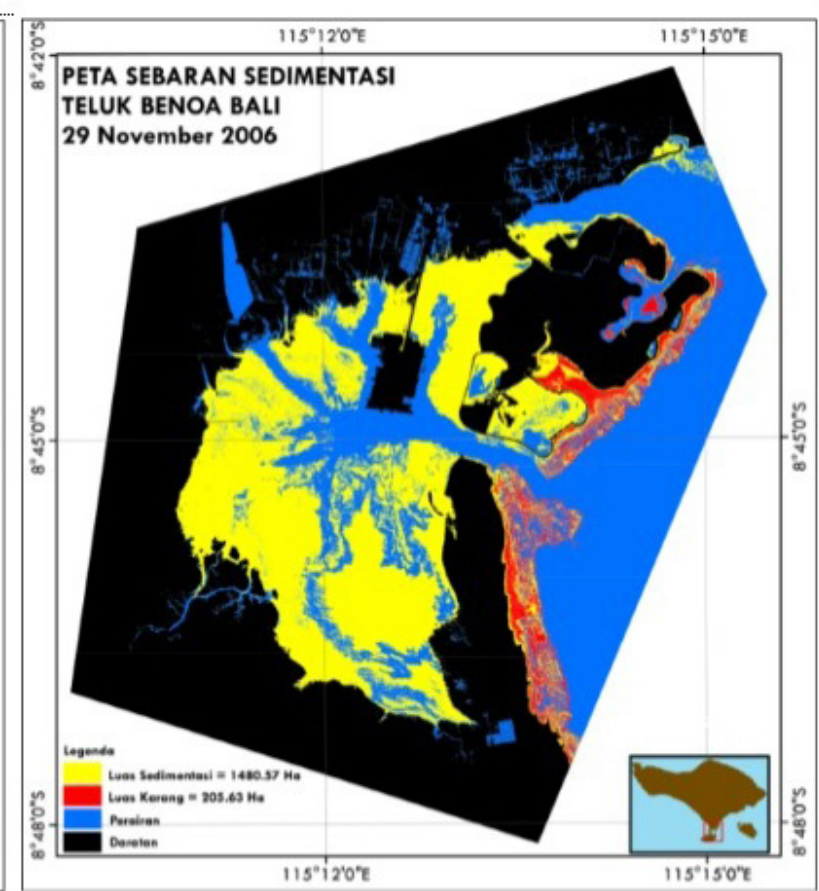

(b)

Gambar 3. Peta Sebaran Sedimentasi di Perairan Teluk Benoa Bali: (a) Analisis Citra Landsat 7 Tahun 1997 dan (b) Citra Spot - 6 Tahun 2006).

Figure 3. Sedimentation Distribution Map in The Waters of Benoa Bay Bali: (a) Landsat Image Analysis 7 Year 1997 and (b) Spot Image - 6 Year 2006). 


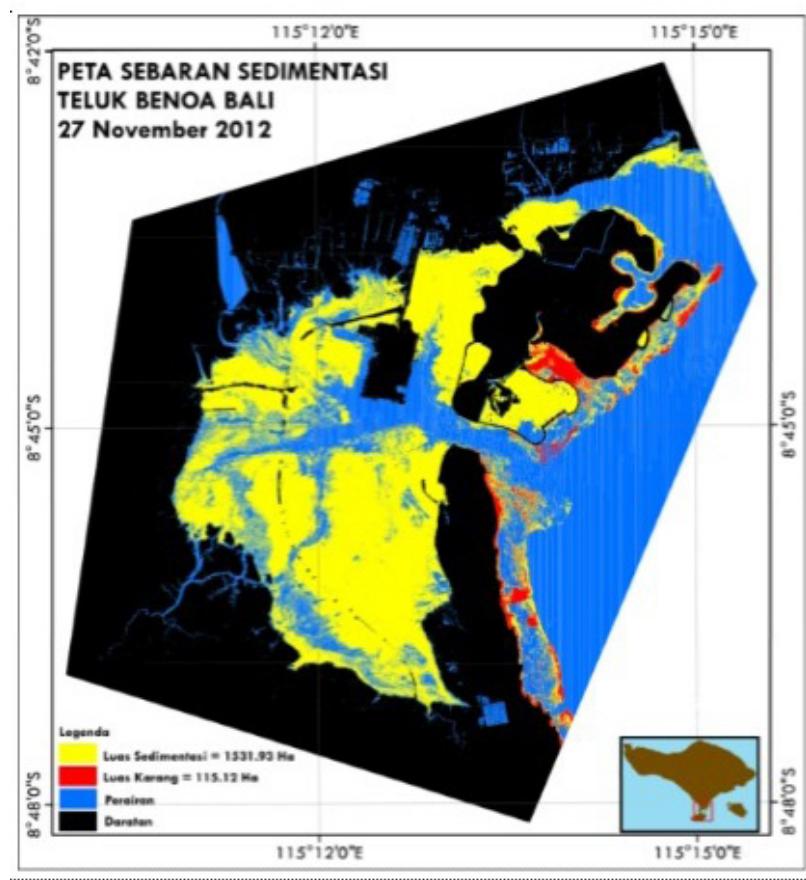

(a)

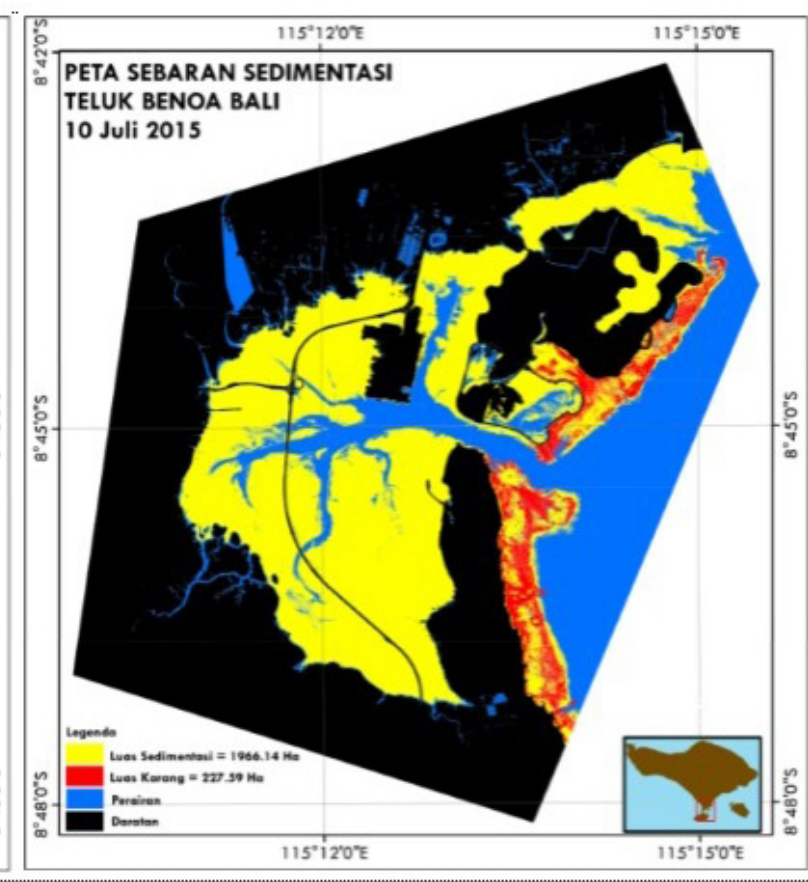

(b)

Gambar 4. Peta Sebaran Sedimentasi di Perairan Teluk Benoa Bali: (a) Analisis Citra Spot - 6 Tahun 2012 dan (b) Analisis Citra Spot - 6 Tahun 2015.

Figure 4. Sedimentation Distribution Map in Teluk Benoa Waters of Bali: (a) Spot Image Analysis - 6 of 2012 and (b) Spot Image Analysis - 6 Year 2015.

\section{KESIMPULAN DAN SARAN}

Pendangkalan di perairan Teluk Benoa nyata terjadi, dengan kejadian sedimentasi cukup luas menunjukkan perubahan luasan dari tahun 1997 - 2006 mengalami penurunan seluas positif -160,21 ha, tahun $2006-2012$ mengalami peningkatan seluas negatif $+51,36$ ha dan tahun $2012-2015$ terjadi peningkatan drastis seluas negatif $+434,21$ ha. Laju sedimentasi secara spasial dari tahun 1997 sampai 2006 terjadi penurunan sebesar positif $-20,03$ ha/tahun, peningkatan pada rentang tahun $2006-2012$ sebesar negatif $+8,56$ ha/tahun dan tahun 2012 - 2015 sebesar negatif $+144,74$ ha/tahun. Pemetaan sedimentasi secara spasial di kawasan Teluk Benoa menunjukkan bahwa pesatnya pembangunan di kawasan Teluk Benoa selama 10 tahun terakhir dominan lebih memanfaatkan lahan kosong, perairan (Tol dan Pulau Serangan) untuk pembangunan wilayah di kawasan Teluk Benoa, pembangunan yang pesat tersebut berimbas pada pendangkalan perairan laut akibat sedimentasi yang tiap tahun pengalami peningkatan luasan di kawasan perairan Teluk Benoa.

\section{UCAPAN TERIMA KASIH}

Ucapan terima kasih Penulis Pertama sampaikan kepada Kepala LRSDKP KKP Bungus sekaligus sebagai Ketua Kelti Sumber Daya dan Kerentanan
Pesisir LRSDKP, atas dukungan dan ikut serta dalam pelaksanaan kegiatan ini. Terimakasih juga kepada Peneliti Senior Pusriskel, Bapak Widodo S. Pranowo atas bimbingan dan koreksi pada tulisan ini, kepada Peneliti Senior Pusriskel, Bapak Semeidi Husrin atas bimbingannya. Serta teman-teman teknisi dan administrasi LRSDKP yang membantu terlaksananya seluruh kegiatan penelitian sampai selesai.

\section{DAFTAR PUSTAKA}

[Balitbang KKP] Badan Litbang KKP. (2016). Citra satelit INDESO Project: perekaman tahun 2006, 2012, dan 2015.

[BWS] Balai Wilayah Sungai Bali - Penida. (2016). Informasi pembangunan bendungan di Muara Tukad Badung.

Carolita, I., J. Sitorus, J. Manalu., \& D. Wiratmoko. 2015. Growth profile analysis of oil palm by using SPOT 6 the case of North Sumatra. Int. J. Remote Sensing and Earth Sciences 22(1): 2126.

Dahuri. R., Rais. J., Ginting. S. P., \& Sitepu. M. J., (2013). Pengelolaan Sumber Daya Wilayah Pesisir dan Lautan Secara Terpadu. Jakarta: Balai Pustaka. 328 hal.

Darmawan, I. G., \& Surya. (2013). Pemanfaatan Lahan Pra dan Pascareklamasi di Pulau Serangan. 
Program Pascasarjana. Tesis. Universitas Udayana.

Dhiaududdin, R., Gemilang, W. A., Wisha, U. J. (2017). Pemetaan Kerentanan Pesisir Pulau Simeulue Dengan Metode CVI (Coastal Vulnerability Index). EnviroScienteae 13(2): 157-170.

[ENVI] Exelis Visual Information Solution Classic help. (2008). ENVI Classic Tutorial: Classfication Method. Software.

Gemilang, W.A., Husrin, S., Wisha, U. J., \& Kusumah, G. (2017a). Kerentanan Pesisir Terhadap Bencana Tanah Longsor di Bungus, Sumatera Barat dan Sekitarnya Menggunakan Metode Storie. J. Geosaintek 3(1): 37-44.

Gemilang, W. A., Wisha, U. J., Kusumah, G. (2017b). Distribusi sedimen dasar sebagai identifikasi erosi pantai di Kecamatan Brebes menggunakan analisis granulometri. J. Kelautan 10(1): 54-66.

Gemilang, W.A., Kusumah, G., Wisha, U. J., \& Arman, A. (2017c). Laju sedimentasi di Perairan Brebes Jawa Tengah menggunakan metode Isotop 210Pb. J. Geologi Kelautan 15(1): 11-22.

Jamalludin., Fatoni, K. I., Alam, T. M., \& Pranowo, W. S. (2016). Identifikasi Banjir Rob Periode $2013-$ 2015 Di Kawasan Pantai Utara Jakarta. J. Chart Datum 2 (2): 1-11.

Leeder. M. R. (1982). Sedimentology Process and Product. London: George Allen \& Unwin Press. 344 hal.

LPSDKP. (2016). Pendangkalan di perairan Teluk Benoa Bali. Dokumentasi Teknis. Kementerian Kelautan dan Perikanan

LPSDKP. (2016). Kajian Dampak Reklamasi Teluk Benoa Terhadap Ekosistem Laut dan Pesisir. Laporan Akhir Kegiatan Penelitian. Kementerian Kelautan dan Perikanan.

Muldiyatno, F., Djunarsjah, E., Adrianto, D., \& Pranowo, W. S. (2016). Kajian Awal Perubahan Muka Air Sungai untuk Penentuan Datum Peta (Studi Kasus Sungai Musi Palembang). J. Chart Datum 1 (2): 36-42.

Pabundu. T. (2005). Metode Penelitian Geografi. Jakarta: Bumi Aksara. 180 hal.

Parwati, E., \& Purwanto, A. D. (2017). Time series analysis of Total Suspended Solid (TSS) using Landsat Data in Berau Coastal Area, Indonesia. Int. J. Remote Sensing and Earth Sciences 14(1): 61-70.

Pearson, S., Windupranata, W., Pranowo, W. S., Putri, A., Ma, Y., Vila-Concejo, A., Fernández, E., Méndez, G., Banks, J., Knights, A. M., Firth, L. B., Breen, B. B., Jarvis, R., Aguirre, J. D., Chen, S., Smith, A. N. H., Steinberg, P., Chatzinikolaou,
E., \& Arvanitidis, C. (2016). Conflicts in some of the World harbours: what needs to happen next?. Maritime Studies (2016) 15:10. 23 pages. DOI:10.1186/s40152-016-0049-x.

Rachman, Herlambang Aulia., I Gede Hendrawan, \& I Dewa Nurwede Putra. (2016). Studi Transpor Sedimen di Teluk Benoa Menggunakan Pemodelan Numerik. Jurnal Kelautan Trunojoyo: Vol. 9 (No.2).

Risandi, J., Sagala, S.L., \& Pranowo, W. S. (2015). Aplikasi model numerik karakteristik gelombang untuk kajian kesesuaian lahan pengembangan budidaya laut di Situbondo, Jawa Timur. $J$. Kelautan Nasional 10(1): 21-31.

Sarbidi. (2005). Pengaruh ROB Pada Pemukiman Pantai (Kasus Semarang). Makalah dan Presentasi Kerugian pada Bangunan dan Kawasan Akibat Kenaikan Muka Air Laut pada Kota - Kota Pantai di Indonesia, Bandung.

Sudiarta, K., Hendrawan, I. G., Putra, K. S., \& Dewantama, I. M. I. (2012). Kajian Modeling Dampak Perubahan Fungsi Teluk Benoa Untuk Sistem Pendukung Keputusan (Decision Support System) Dalam Jejaring KKP Bali. Laporan Teknis. Conservation International Indonesia.

Tanto, T. A., Wisha, U. J, Kusumah, G., Pranowo, W. S., Husrin, S., Ilham, I \& Putra, A (2017). Karakteristik Arus Laut Perairan Teluk Benoa Bali. J. Ilmiah Geomatika 23(1): 37-48.

[USGS] U.S. Geological Survey. (2016). Satelit Landsat 7 ETM: perekaman tahun 1997.

[UU] Undang - Undang RI Nomor 1 Tahun 2014 Tentang Perubahan Atas UU No. 27 Tahun 2007 Tentang Pengelolaan Wilayah Pesisir dan Pulau - Pulau Kecil.

Wisha, U.J., Husrin, S., Prihantono, J. (2015). HIdrodinamika Perairan Teluk Banten Pada Musim Peralihan (Agustus-September). J. Ilmu Kelautan 20(2): 101-112.

Wisha, U.J., Yusuf, M., \& Maslukah, L. (2014). Sebaran muatan padatan tersuspensi dan kelimpahan fitoplankton di perairan muara Sungai Porong Kabupaten Sidoarjo. J. Oseanografi 3(3): 454461. 